\title{
Effect of intramuscular tramadol hydrochloride as a labor analgesic in primagravidae
}

\author{
Asha Rani K. N. M.* \\ Department of Obstetrics \& Gynaecology, VIMS, Bellary, Karnataka, India \\ Received: 22 January 2016 \\ Accepted: 04 February 2016 \\ *Correspondence: \\ Dr. Asha Rani K.N.M., \\ E-mail: drasharani689@gmail.com \\ Copyright: (c) the author(s), publisher and licensee Medip Academy. This is an open-access article distributed under \\ the terms of the Creative Commons Attribution Non-Commercial License, which permits unrestricted non-commercial \\ use, distribution, and reproduction in any medium, provided the original work is properly cited.
}

\begin{abstract}
Background: Labour pain is among the most severe pain experienced by women. The need for analgesia to overcome pain in labour is highly requested by women today. In developing nations where availability of facilities is the main limiting factor, intramuscular opioids can be considered.

Methods: This study was conducted in teaching. 200 low risk primigravidae who fulfilled the selection criteria with full-term pregnancy with vertex presentation with good uterine contractions and already in active phase of labour were given $100 \mathrm{mg}$ tramadol hydrochloride intramuscularly.

Results: 200 primigravidae before giving the drug, no patient had grade-I or no pain, $19 \%$ had grade-III and $81 \%$ had grade-IV pain. After administration of tramadol hydrochloride IM there was reduction of pain from grade-III and grade IV by $52.49 \%$ and all of the patients continued with grade-II pain in 2nd stage and delivered normally and only 6 women had minimal side effects like nausea and vomiting.

Conclusions: In low risk primigravidae, IM tramadol hydrochloride appears to be effective with minimal side effects. Hence, in developing nations, where availability of facilities is the main limiting factor, IM opioids can be considered as suitable alternatives.
\end{abstract}

Keywords: Labor analgesia, Tramadol hydrochloride intramuscular

\section{INTRODUCTION}

Giving birth is a painful process. This applies to all social and ethnic groups and has probably been so since mankind walked up right. ${ }^{1}$ Labour and delivery cause pain in most patients. Nulliparous women are more likely to experience severe pain than multiparous women. ${ }^{2}$ Pain of labour is rarely surpassed and frequently exceeds the woman's antepartum expectation. Rickford and Regnolds suggest that it is not that women underestimate the pain but tend to overestimate their ability to cope with it. ${ }^{3}$

The need for analgesia to overcome pain in labour is highly requested by women today. Various ways either non-pharmacologic e.g., emotional sustain, psychoprophylactic preparation, yoga and hypnosis or pharmacologic such as epidural blockade or parenteral are used. $^{4}$ Labour can be both physically and psychologically stressful for a woman and the resulting detrimental effects on the fetus are well documented. ${ }^{5}$ And adequate analgesia during labour is of benefit to the mother and has a positive influence on the course of labour and the state of newborn child. Thus making obstetrical analgesia an essential part of modern obstetrics. ${ }^{6}$

The experience of labour pain is a highly individual reflection of variable stimuli that are uniquely received and interpreted by each woman individually. These stimuli are modified by emotional, motivational, cognitive, social and cultural circumstances. Choice among a variety of methods and individualization of pain relief is desirable. ${ }^{7}$ 
An ideal analgesic technique used should be cheap, easy to administer, produce good and reliable relief from pain but not impair consciousness/ cooperation. It should be not toxic to mother and fetus and not produce cardiorespiratory depression in the fetus. The technique must have no tocolytic action and not delay labour. ${ }^{8}$

Epidural analgesia has been popularly used for pain relief in western countries for nearly three decades. In India, its use is limited due to lack of awareness, trained staff and monitoring facilities and injectable opioids such as meperidine and tramadol are reasonably used. ${ }^{9}$ Tramadol, a weak opioid agent inhibits noradrenergic and serotonergic neurotransmission, having analogous analgesic efficacy to meperidine and less sedative effect on the mother and less neonatal respiratory depression. ${ }^{10}$

\section{METHODS}

\section{Source and data collection}

200 primigravid women presenting with full term pregnancy at Tertiary care hospital

\section{Inclusion criteria}

All primigravid women presenting with:

- Full term pregnancy

- Vertex presentation

- Singleton live fetus

- In active phase of labour with engaged head for vaginal delivery.

\section{Criteria for active labour}

- 3-5 cm of cervical dilatation

- Fully effaced cervix

- Good uterine contractions i.e., contractions lasting for at least 25-30 seconds and 3 such contractions in a period of $10 \mathrm{~min}$.

\section{Exclusion criteria}

- Parturients with any associated history of medical disorders.

- Any associated obstetrical complication with multiple gestation, APH, placenta previa, IUGR, CPD, epilepsy, psychiatric disorders

- History of hypersensitivity to drug.

Once the patient is in established active phase of labour i.e., $\geq 3 \mathrm{cms}$ dilatation, full effacement with good uterine contractions, vital signs recorded and primary investigations done and pain score was noted before administering the drug. Injection tramadol $100 \mathrm{mg}$ IM was given as a single dose depending on condition of the patient i.e., $2 \mathrm{mg} / \mathrm{Kg}$ / body weight. Pulse rate, respiratory rate, blood pressure, FHR were recorded. Patient was advised to inform as soon as pain begins to decrease in intensity or even if there is no pain relief at all. Partogram was marked to assess the progress of labour.

The following observations were recorded:

1. Onset of action of the drug

2. Drug side effects, change in vital parameters at first every $30 \mathrm{~min}$, then at hourly were monitored.

3. FHR monitoring was done clinically and any variability noted.

4. Progress of labour was monitored clinically.

5. Assessment of analgesia was done hourly by scoring system, injection repeated every 3 hours, not exceeding $400 \mathrm{mg} /$ day.

6. Patient level of consciousness, alertness, and psychological disturbances was judged.

7. The duration of labour, degree of pain relief in first and $2^{\text {nd }}$ stage, the total dose of tramadol given, the mode of delivery and recovery time in each patient was noted and recorded.

8. Apgar score at 1 and 5 minutes interval after delivery of neonate was recorded.

9. Any complications during the course of labour were recorded. Patient was observed for 2 hours after delivery and was shifted to the ward if there were no complications.

\section{Assessment of pain relief}

The degree of pain relief was assessed in the following manner.

It is almost impossible to comprehend the degree of pain and agony women endure during delivery. It's a challenge to measure pain. Various methods exists, but none, which can guarantee pain measurement conclusively. During the course of this study pain relief after administration of the drug was analyzed and recorded using the rupees scale.

\section{Rupees scale}

The degree of pain relief was expressed as percent of the whole rupee. The degree of pain was graded as shown below:

Grade-I No pain .0

Grade-II Mild pain but comfortable.............25\%

Grade-III Moderate pain with discomfort.......50\%

Grade-IV Maximum pain / severe pain........ $\geq 75 \%$

\section{RESULTS}

In this study, 200 patients of different age group were studied to evaluate the efficacy and safety of tramadol hydrochloride in providing pain relief during labour and its side effects on mother and the newborn. 
Table 1: Showing the age group of women in the study group.

\begin{tabular}{|lll|}
\hline Age group (in years) & No. of women & Percentage \\
\hline $15-19$ & 47 & 23.5 \\
\hline $20-24$ & 121 & 60.5 \\
\hline $25-29$ & 29 & 14.5 \\
\hline $30-34$ & 03 & 1.5 \\
\hline Total & 200 & 100 \\
\hline
\end{tabular}

From the above, maximum of $60.5 \%$ are in the age group of 20 to 24 years and $23.5 \%$ are in the age group of 15 to 19 years. About $14.5 \%$ are in the age group 25 to 29 years and $1.5 \%$ is in the age group 30 to 34 years.

Mean age of women in the study: 22.03 years.

Standard deviation: 3.31 years

95\% confidence limits for age: (21.56 years, 22.49 years).

Table 2: Summary of statistical analysis of study.

\begin{tabular}{|c|c|c|c|}
\hline Variables & $\begin{array}{l}\text { Mean } \\
\text { value }\end{array}$ & $\begin{array}{l}\text { Standard } \\
\text { deviation }\end{array}$ & $\begin{array}{l}95 \% \\
\text { Confidence } \\
\text { interval }\end{array}$ \\
\hline Age in years & 22.03 & 3.31 & $(21.56,22.49)$ \\
\hline $\mathrm{EFW}$ in $\mathrm{Kg}$ & 2.79 & 0.42 & $(2.73,2.85)$ \\
\hline \multicolumn{4}{|c|}{ Duration of labour } \\
\hline Stage I & 3.72 & 2.22 & $(3.41 \mathrm{~h}, 4.03 \mathrm{~h})$ \\
\hline Stage II & 20.46 & 11.38 & $(18.88,22.04)$ \\
\hline Stage III & $\begin{array}{l}5.595 \\
\text { minute }\end{array}$ & 2.310 & $\begin{array}{l}(5.27 \mathrm{sec}, 5.91 \\
\mathrm{sec})\end{array}$ \\
\hline $\begin{array}{l}\text { Injection } \\
\text { delivery } \\
\text { interval } \\
\text { (hours) }\end{array}$ & 1.76 & 1.18 & $\begin{array}{l}\text { (1.59 hour, } \\
1.92 \text { hours) }\end{array}$ \\
\hline \multicolumn{4}{|l|}{ Pain score } \\
\hline \multicolumn{4}{|c|}{ Before admission of drug } \\
\hline Stage I & 3.81 & 0.39 & $(3.75,3.86)$ \\
\hline \multicolumn{4}{|c|}{ After admission of drug } \\
\hline Stage I & 2.00 & & \\
\hline Stage II & 2.00 & & \\
\hline
\end{tabular}

Before administration of drug at stages I, maximum patients i.e. $16281 \%$ are having grade IV type of pain. After administration of drug maximum patients i.e. 200 $(100 \%)$ having grade II type of pain. The mean degree of pain before administration of drug is $3.81 \pm 0.39$. After administration of drug the mean degree of pain is 2 . The mean reduction of pain is $52.49 \%$.

\section{DISCUSSION}

The ACOG 2002b recently reaffirmed its position published jointly with the American Society of Anaesthesiologists that a request for pain relief by the woman is sufficient medical indication for its use. ${ }^{11}$
Table 3: Degree of pain relief.

\begin{tabular}{|llll|}
\hline $\begin{array}{l}\text { Degree of } \\
\text { pain }\end{array}$ & $\begin{array}{l}\text { Before } \\
\text { admn of } \\
\text { drug stage }\end{array}$ & $\begin{array}{l}\text { After } \\
\text { admn of } \\
\text { drug stage } \\
\text { I }\end{array}$ & $\begin{array}{l}\text { After } \\
\text { admn of } \\
\text { drug stage } \\
\text { II }\end{array}$ \\
\hline Grade I & 0 & 0 & 0 \\
\hline Grade II & 0 & $200(100 \%)$ & $200(100 \%)$ \\
\hline Grade III & $38(19 \%)$ & 0 & 0 \\
\hline Grade IV & $162(81 \%)$ & 0 & 0 \\
\hline Total & 200 & 200 & 200 \\
\hline $\begin{array}{l}\text { Mean } \\
\text { degree of } \\
\text { pain }\end{array}$ & 3.81 & 2.00 & 2.00 \\
\hline SD of pain & 0.39 & - & - \\
\hline $\begin{array}{l}\text { 95\% CI } \\
\text { for mean } \\
\text { degree of } \\
\text { pain }\end{array}$ & $(3.75,3.86)$ & - & - \\
\hline
\end{tabular}

In a scholarly review Lowe, emphasized that the experience of labour pain is a highly individual reflection of variable stimuli that are uniquely received and interpreted by each woman individually. ${ }^{12}$

Heever and Kell described the technique of pain score for assessment of the efficacy of the various forms of analgesia. It is hard to compare the analgesic effects of the drugs since it depends on subjective evaluation of the pain. However studies indicated tramadol as an effective analgesic that can be used for the treatment of intense acute and chronic pain such as postoperative and obstetric pain. $^{13}$

Tramadol hydrochloride, a narcotic drug introduced in Germany is available throughout the world. In obstetric analgesia, $100 \mathrm{mg}$ tramadol hydrochloride administered intramuscularly has an analgesic effect equivalent to that of $100 \mathrm{mg}$ pethidine or $10 \mathrm{mg}$ morphine, administered intramuscularly. ${ }^{14}$

Tramadol is a weak opioid analgesic, which interacts with $\mu, \delta, \kappa$ opioid receptors, where it exhibits purely agonist effects. ${ }^{15}$

In the present study, the effect of intramuscular tramadol when given to 200 primigravid woman in labour of age 18 - 35 years were studied.Similar studies were conducted earlier.

One was by Jain S, Arya VK et al at the Department of Obstetrics \& Gynecology and Department of Anesthesia, Post Graduate Institute of Medical Education \& Research, Chandigarh, India during 2003, where intramuscular tramadol and intramuscular meperidine were compared with epidural analgesia. Another similar study was carried out by Thakur Ratna, Patidar Rekha, Department of Obstetrics \& Gynecology, MGM Medical College and MY Hospital, Indore, India. 


\section{Age incidence}

In our study, there was no significant variation in the age incidence.

Table 4: Comparison of age with Keskin et al. ${ }^{16}$

\begin{tabular}{lll} 
& Keskin et al (IJGO) & Present study \\
Mean age & 22.43 & 22.03 \\
\hline
\end{tabular}

From the above table, it can be observed that the mean age is comparable with the study of Keskin et al.

\section{Mode of delivery}

In the present study $100 \%$ of patients had full-term normal delivery, wherein the study conducted by Thakur Ratna and Meena Jyoti, Singhal Prabha et al showed 98\% full-term normal delivery and $2 \%$ with forceps delivery. Injection oxytocin and injection drotine was used wherever necessary.

Table 5: Comparative analysis of mode of delivery.

\begin{tabular}{|c|c|c|c|c|c|c|c|c|}
\hline $\begin{array}{l}\text { Mode } \\
\text { of } \\
\text { delivery }\end{array}$ & $\begin{array}{l}\text { Thakur } \\
\text { Ratna } 17 \\
\text { IJOG }\end{array}$ & $\begin{array}{l}\text { Keshin } \\
16 \\
\text { IJOG }\end{array}$ & $\begin{array}{l}\text { Prasert- } \\
\text { sawat }^{18} \\
\text { CTR }\end{array}$ & $\begin{array}{l}\text { Sarkar }^{19} \\
\text { IJOG }\end{array}$ & $\begin{array}{l}\text { Bajaj }^{20} \\
\text { IP }\end{array}$ & $\begin{array}{l}\text { Hussein } \\
\text { Gerburtsh, } \\
\text { Perinatol }^{21}\end{array}$ & $\begin{array}{l}\text { Prabha } \\
\text { Singhal } \\
\text { JOGI }^{22}\end{array}$ & $\begin{array}{l}\text { Present } \\
\text { study }\end{array}$ \\
\hline FTND & 98 & 57 & 93 & 72 & 82 & 79 & 98 & 200 \\
\hline LSCS & -- & 2 & 2 & 8 & 10 & 3 & -- & -- \\
\hline Ventose & -- & -- & 5 & -- & 3 & 10 & -- & -- \\
\hline Forceps & 2 & -- & -- & 20 & 5 & 8 & 2 & -- \\
\hline Total & 100 & 59 & 100 & 100 & 100 & 100 & 100 & 200 \\
\hline
\end{tabular}

Mode of delivery was comparably good enough to the other standard studies of the series, where the incidence of operative deliveries had decreased with the use of tramadol.

\section{Effectiveness of analgesia and degree of pain relief}

There is no doubt that labor pain is one of the most intense pains experienced but the perception of pain varies strikingly between individuals. ${ }^{15}$
Out of 200 patients in the present study before giving the drug, no patient had grade-I or no pain, $19 \%$ had gradeIII and $81 \%$ had grade-IV i.e., maximum pain.

After administration of $100 \mathrm{mg}$ tramadol intramuscularly in the first stage, there was reduction of pain from grade III and IV to grade II i.e. by $52.49 \%$ in 200 patients and these 200 patients continued in the second stage with grade-II pain. This assessment holds well with studies conducted by Thakur Ratna, etc.

Table 6: Comparative analgesic of pain relief.

\begin{tabular}{|c|c|c|c|c|c|c|c|}
\hline $\begin{array}{l}\text { Degree of } \\
\text { pain relief }\end{array}$ & $\begin{array}{l}\text { Thakur } \\
\text { ratna }^{17} \text { IJGO }\end{array}$ & $\begin{array}{l}\text { Prasertsa } \\
\text { wat CTR }^{18}\end{array}$ & $\begin{array}{l}\text { Bajaj } \\
\text { IP }^{20}\end{array}$ & $\begin{array}{l}\text { Hussein } \\
\text { Gerburtsh } \\
\text { perinatol }^{21}\end{array}$ & $\begin{array}{l}\text { Sarkar } \\
\text { Jogi }^{19}\end{array}$ & $\begin{array}{l}\text { Prabha } \\
\text { Singhal } \\
\text { JOGI }^{22}\end{array}$ & $\begin{array}{l}\text { Present } \\
\text { study }\end{array}$ \\
\hline No relief & 14 & 22 & 20 & 1 & 2 & 0 & -- \\
\hline Mild relief & 16 & -- & 33 & 20 & 47 & 14 & -- \\
\hline $\begin{array}{l}\text { Moderate } \\
\text { satisfactory } \\
\text { relief }\end{array}$ & 55 & 53 & 38 & 49 & 38 & 32 & 200 \\
\hline $\begin{array}{l}\text { Complete } \\
\text { relief }\end{array}$ & 15 & 25 & 9 & 30 & 13 & 54 & -- \\
\hline Total & 100 & 100 & 100 & 100 & 100 & 100 & 200 \\
\hline
\end{tabular}

Pain relief was comparably good enough to the other standard study of the series where there was a moderate relief of pain in the present study as compared to the other studies mentioned above. All the patients 200 $(100 \%)$ in our study group had pain relief as only comparable to the closest compares Hussein (99\%), Sarker (98\%), Veiges (91\%). 
This has proved beyond doubt that tramadol has very good efficacy as analgesia in labour and it has decreased the intensity of pain in both $1^{\text {st }}$ and $2^{\text {nd }}$ stage of labour.

\section{CONCLUSIONS}

In the 1st stage degree of pain has significantly reduced from severe and moderate pain to mild pain in most of the subjects and in the 2nd stage, the degree of pain continued to be mild. It was found that tramadol was a safe and satisfactory drug for relief of labour pain.

\section{Funding: No funding sources}

Conflict of interest: None declared

Ethical approval: The study was approved by the Institutional Ethics Committee

\section{REFERENCES}

1. Rudra A. Article 3: 1 of 2 Update in Anesthesia. 2004;18.

2. Melzack R. The Myth of painless childbirth. Pain 1984;19:321-37.

3. Rickford WJK, Reynolds. Expectations and experiences of pain relief in labour. The Society for Obstetric Anesthesiology \& Perinatology. Halifaa, Novascotia. 1987:163.

4. Fieni S, Ageri C, Kaihura CT. Perinatal effects of 2 analgesics, Tramadol chloryhydrate and Meperidine Chlorhydrate, when used during labour. Acta Biomedical de Pateneo Parmensa Supplement. 2000;71:397-400.

5. Pritchard JA, MacDonald PC, Gant NF, Williams Obstetrics, 7th Ed., Norwalk, Appleton Century, Crofts, 1985: 353 pp.

6. Viegar OAL. Tramadol in labour pain in primiparous patients - A prospective comparative clinical trial. E J Obst \& Gynec \& Reprod Biology. 1993;49:131-5.

7. Lowe NK. The nature of labour pain. Am J Obstet. Gynecol. 2002;106:316.

8. Lan Lee TS, Tat L. Pain relief in labour - The Management of Labour. S. Arulkumaran, Ratnam SS, Bhaskar Rao Ed.

9. Jain S. Analgesic efficacy of intramuscular opoids versus epidural analgesia in labour. Int $\mathbf{J}$ of Gynecology \& Obstet. 2003;83(1):19-27.

10. Elhakim M, Abd El-Megid W, Metry A, El-hennawy A, El-Queseny K. Analgesic and antacid properties of IM tramadol given before cesarean section under general anesthesia. British Journal of Anaesthesia, 2005;95(6):811-5.

11. Williams Obstetrics, Normal Labour. 22nd Edition: Obstetrical Anaesthesia, Chapter: 19, Page: 474.

12. Williams Obstetrics, Normal Labour. 22nd Edition: Obstetrical Anaesthesia, Chapter: 19, Page: 475.

13. Heever HT, Keele CA. Method of testing analgesia in man. Lancet. 1948;1:683.

14. Singh S, Mathur V, Srivastava U, Pandey DFN, Gupta N. Comparative evaluation of efficacy of tramadol with pentazocine for labour analgesiaand their effects on fetal outcome. J Obstet \& Gyn. Of India. 2001;51(2):55-7.

15. Brinbach D. Pain Mechanism in labour. Stephen Pgatt, Sanjay Dutta in: Textbook of Obstetric Anaesthesia in: Chapter-I, Physiology, Pharmacology and Anatomy.

16. Keskin HL, Aktepe K. Pethidine versus tramadol for pain relief during labour. International Journal of Gynecol \& Obstet. 2003;82(1):11-6.

17. Thakur R, Patidar R. Comparative study of transcutaneous electrical nerve stimulation (TENS) and tramadol hydrochloride for pain relief in labour. J. Obstet. Gynecol Ind. 2004;54(4):346-50.

18. Pratak OP, Herabutya Y, Chatura C. Obstetric analgesia: Comparison between tramadol, morphine and pethidine. Curr Ther Res. 1986;40(6):1022-8.

19. Sarkar B, Mukhopadhyay AK. Tramadol hydrochloride in dysfunctional labour a clinical trial. The Journal of Obst and Gyn of India. 1997;47(1):42-7.

20. Bajaj P, Meena R, Prasad R. Intravenous tramadol for labour analgesia. The Indian Practitioner. 1997;50(12):1051-4

21. Husshein P, Kubista E. Obstetrical analgesia with tramadol - Results of a prospective randomized comparative study with pethidine. Z Geburtshilfe. Perinatol. 1987;191(6):234-7.

22. Meena J, Singhal P, Choudhary D. The programmed labor. J Obstet Gynecol India. 2006;56:53-5.

Cite this article as: Asha Rani KNM. Effect of intramuscular tramadol hydrochloride as a labor analgesic in primagravidae. Int $\mathrm{J}$ Reprod Contracept Obstet Gynecol 2016;5:615-9. 